\title{
Insulin and Glucagon Concentrations in Portal and Peripheral Veins in Patients with Hepatic Cirrhosis
}

\author{
A. V. Greco, F. Crucitti ${ }^{1}$, G. Ghirlanda, R. Manna, L. Altomonte, A. G. Rebuzzi, and A. Bertoli \\ Istituto di Patologia Medica and ${ }^{1}$ Istituto di Semeiotica Chirurgica, Catholic University, Rome, Italy
}

Summary. The portal vein was catheterized via the umbilical vein under local anaesthesia in 10 nondiabetic subjects about to undergo exploratory laparotomy and in 8 patients with liver cirrhosis. Immunoreactive insulin (IRI) and glucagon (IRG) were assayed in portal and peripheral blood before and during IV infusion of glucose $(0.33 \mathrm{~g} / \mathrm{kg})$ or arginine $(25 \mathrm{~g})$. Basal peripheral plasma (IRI) levels were raised in cirrhotic patients (19 \pm 2 versus $10 \pm$ $1 \mu \mathrm{U} / \mathrm{ml} ; \mathrm{P}<0.001)$. Basal portal insulin values, however, did not differ in the two groups. After glucose cirrhotic patients had higher peripheral insulin concentrations, compared to controls, significant at 45 and 60 minutes. In contrast portal insulin levels were higher in controls than in cirrhotics by 1 minute ( $403 \pm 43$ versus $158 \pm 38 \mu \mathrm{U} / \mathrm{ml} ; \mathrm{P}<0.001$ ) and remained so for the 60 minutes of study. Similarly, after arginine cirrhotics had significantly higher peripheral insulin concentrations and lower portal concentrations than controls. Peak portal vein insulin levels were delayed in cirrhotics $(168 \pm 16 \mu \mathrm{U} / \mathrm{ml}$ at $3 \mathrm{~min})$ compared with controls $(413 \pm 25 \mu \mathrm{U} / \mathrm{ml}$ at 1 $\mathrm{min})$. In the basal state both portal and peripheral glucagon levels were higher in cirrhotics than control subjects. Unlike in controls, IV glucose did not suppress glucagon secretion in cirrhotic patients. Peripheral plasma glucagon concentrations after arginine were also consistently higher in cirrhotics than controls, but unlike insulin portal venous glucagon levels were also raised $(1800 \pm 360 \mathrm{pg} / \mathrm{ml}$, cirrhotics; $960 \pm 87 \mathrm{pg} / \mathrm{ml}$, controls; $\mathrm{P}<0.001 ; 1 \mathrm{~min}$ after arginine infusion). We conclude that insulin secretion is decreased in liver cirrhosis and that the peripheral hyperinsulinaemia observed reflects diminished hormone metabolism. The high plasma glucagon levels observed in cirrhotic patients are the result of pancreatic hypersecretion of glucagon.
Key words: Insulin, glucagon, portal blood, glucose, arginine, liver cirrhosis.

Most studies of insulin secretion in normal and cirrhotic subjects have determined peripheral plasma insulin concentrations on the assumption that changes observed peripherally reflected identical changes in pancreatic insulin secretion. However factors other than secretion may influence peripheral insulin concentrations. The liver has been shown to be the major site of insulin breakdown; about $50 \%$ of the insulin secreted by the pancreas is broken in the liver at a single passage $[13,20,22,23,29,32,33$, $35,36,38]$. In liver cirrhosis this hepatic degradation of insulin may be influenced by parenchymal damage and portacaval shunts. In addition, the liver contributes to glucagon removal, [1, 17, 21, 26, 36], although the kidneys seem to be of major importance $[27,39]$. Impaired hepatic function could therefore also influence plasma glucagon levels independent of glucagon secretion. Data concerning plasma insulin patterns in liver cirrhosis are conflicting: some authors have described insulin resistance associated with hyperinsulinism $[2,6,8,12,24,31,37,42]$ while others have shown reduced insulin secretion $[9$, $16,18]$. On the other hand, there is a general agreement that glucagon levels are increased in cirrhotic patients both at basal conditions and after arginine or alanine $[14,30,40,41]$ administration. All these investigations have been performed on blood specimens drawn from a pcripheral vein either in basal conditions or after a variety of stimuli.

In the present study, insulin and glucagon were assayed in samples of portal blood, drawn via an 
Table 1. Characteristics of cirrhotic patients. AST, aspartate aminotransferase

\begin{tabular}{|c|c|c|c|c|c|c|c|c|c|c|c|}
\hline Subject & Age & $\begin{array}{l}\% \text { ideal } \\
\text { body } \\
\text { weight }\end{array}$ & $\begin{array}{l}\text { Glucose } \\
\mathrm{mg} / 100 \mathrm{ml}\end{array}$ & $\begin{array}{l}\text { IRI } \\
\mu \mathrm{U} / \mathrm{ml}\end{array}$ & $\begin{array}{l}\mathrm{IRG} \\
\mathrm{pg} / \mathrm{ml}\end{array}$ & $\begin{array}{l}\text { Plasma } \\
\text { bilirubin } \\
\mu \mathrm{mol} / 1\end{array}$ & $\begin{array}{l}\text { BSP } \\
\%\end{array}$ & $\begin{array}{l}\text { Plasma } \\
\text { AST } \\
\text { I.U. } / 1\end{array}$ & $\begin{array}{l}\text { Plasma } \\
\text { Albumin } \\
\mathrm{g} / 1\end{array}$ & $\begin{array}{l}\text { Prothrombin } \\
\text { time } \\
\%\end{array}$ & $\begin{array}{l}\text { Portal } \\
\text { pressure } \\
\mathrm{cm} \mathrm{H}_{2} \mathrm{O}\end{array}$ \\
\hline 1 & 39 & 108 & 105 & 13 & 220 & 32 & 18 & 80 & 22 & 60 & 35 \\
\hline 2 & 47 & 101 & 97 & 25 & 210 & 65 & 16 & 87 & 39 & 71 & 26 \\
\hline 3 & 43 & 99 & 100 & 10 & 200 & 31 & 21 & 100 & 18 & 80 & 29 \\
\hline 4 & 59 & 104 & 73 & 25 & 375 & 67 & 27 & 70 & 35 & 59 & 90 \\
\hline 5 & 57 & 110 & 117 & 17 & 250 & 77 & 19 & 68 & 40 & 73 & 28 \\
\hline 6 & 55 & 108 & 96 & 24 & 350 & 56 & 28 & 94 & 29 & 65 & 48 \\
\hline 7 & 45 & 105 & 82 & 8 & 110 & 36 & 12 & 58 & 31 & 70 & 32 \\
\hline 8 & 49 & 107 & 85 & 18 & 285 & 82 & 15 & 68 & 25 & 68 & 40 \\
\hline $\begin{array}{l}\text { Mean } \\
\text { cirrhotic } \\
\text { value } \\
( \pm \text { SEM) }\end{array}$ & $\begin{array}{r}49 \\
\pm 2\end{array}$ & $\begin{array}{r}105 \\
\pm 2\end{array}$ & $\begin{array}{r}94 \\
\pm 4\end{array}$ & $\begin{array}{r}19 \\
\pm 2\end{array}$ & $\begin{array}{r}250 \\
\pm 27\end{array}$ & $\begin{array}{r}55 \\
\pm 5\end{array}$ & $\begin{array}{l}19.5 \\
\pm 2\end{array}$ & $\begin{array}{r}78 \\
\pm 5\end{array}$ & $\begin{array}{l}30 \\
\pm 2.5\end{array}$ & $\begin{array}{r}68 \\
\pm 2\end{array}$ & $\begin{array}{l}41 \\
\pm 7\end{array}$ \\
\hline $\begin{array}{l}\text { Mean } \\
\text { control } \\
\text { value } \\
( \pm \text { SEM })\end{array}$ & $\begin{array}{r}39 \\
\pm 1\end{array}$ & $\begin{array}{r}103 \\
\pm 1\end{array}$ & $\begin{array}{r}81 \\
+2\end{array}$ & $\begin{array}{r}10 \\
\pm 1\end{array}$ & $\begin{array}{r}105 \\
\pm 15\end{array}$ & $\begin{array}{l}15 \\
\pm 1\end{array}$ & $\begin{array}{r}4.5 \\
\pm 0.5\end{array}$ & $\begin{array}{r}23 \\
\pm 3\end{array}$ & $\begin{array}{r}39 \\
\pm 1\end{array}$ & $\begin{array}{r}98 \\
\pm 1\end{array}$ & $\begin{array}{r}10 \\
\pm 1\end{array}$ \\
\hline
\end{tabular}

Table 2. Portal/peripheral vein insulin ratios (mean \pm SEM) for the integrated area under the curve above basal levels after glucose IV $(0.33 \mathrm{~g} / \mathrm{kg})$ and arginine $(25 \mathrm{~g})$ in control $(\mathrm{n}=10)$ and in cirrhotic subjects $(\mathrm{n}=8) . \mathrm{P}^{*}$ comparing portal/peripheral ratio of cirrhotics with controls

Glucose

\begin{tabular}{|c|c|c|c|c|c|c|c|}
\hline \multirow[b]{2}{*}{ Minutes } & \multicolumn{3}{|c|}{ Control Subjects } & \multicolumn{3}{|c|}{ Cirrhotic Subjects } & \multirow[b]{2}{*}{$\mathrm{P}^{*}$} \\
\hline & Portal area & Peripheral area & Ratio & Portal area & Peripheral area & Ratio & \\
\hline $0-10$ & $2003 \pm 122$ & $273 \pm 18$ & $7.4 \pm 0.7$ & $512 \pm 72$ & $169 \pm 36$ & $3.8 \pm 0.8$ & $<0.025$ \\
\hline $10-60$ & $5287 \pm 733$ & $1062 \pm 181$ & $5.2 \pm 1.1$ & $1420 \pm 151$ & $1200 \pm 112$ & $1.1 \pm 0.5$ & $<0.01$ \\
\hline $0-60$ & $6291 \pm 533$ & $1236 \pm 180$ & $5.8 \pm 0.9$ & $1765 \pm 157$ & $2500 \pm 740$ & $1.2 \pm 0.7$ & $<0.001$ \\
\hline \multicolumn{8}{|l|}{ Arginine } \\
\hline $0-10$ & $1938 \pm 116$ & $159 \pm 19$ & $13.4 \pm 2.5$ & $618 \pm 55$ & $267 \pm 56$ & $3.5 \pm 1.2$ & $<0.005$ \\
\hline $10-60$ & $3487 \pm 295$ & $757 \pm 94$ & $5.0 \pm 0.9$ & $1331 \pm 396$ & $988 \pm 334$ & $2.1 \pm 0.8$ & $<0.05$ \\
\hline $0-60$ & $5425 \pm 278$ & $916 \pm 80$ & $5.7 \pm 1.1$ & $1949 \pm 314$ & $1157 \pm 266$ & $2.8 \pm 1.6$ & $<0.05$ \\
\hline
\end{tabular}

umbilical vein catheter, and in peripheral blood, before and after glucose and arginine infusion, in order to establish whether portal measurements could give more accurate information concerning the pancreatic secretion of these hormones.

\section{Material and Methods}

Ten non-diabetic subjects ( 4 females) aged 33 to $57,103 \pm 1$ (mean \pm SEM) \% ideal body weight, who were about to undergo abdominal surgery, were selected as controls; 2 had gastric ulceration, 2 had gastric carcinoma, 6 had calculous cholecystitis. Fasting blood glucose levels, oral glucose tolerance and liver function tests were normal. All treatment was discontinued during the 48 hours preceding the test; exploratory laparotomy confirmed the absence of liver metastases in patients with gastric carcinoma. The patients were not anaesthetized when the catheter was inserted into the umbilical vein although some had received $5 \mathrm{mg}$ valium prior to the procedure. Eight subjects ( 2 females) with alcoholic cirrhosis were studied. Weight was $105 \pm 2 \%$ ideal body weight; none had ascites; none was diabetic; their ages varied from 36 to 58 years. All patients had normal plasma urea nitrogen, creatinine and radionephrography. The diagnosis of cirrhosis was based on laboratory findings and on the appearance of a hobnail liver during laparoscopy; diagnosis was confirmed by histology. Subjects were hospitalized at the Istituto di Patologia Medica, Catholic University, Rome. They were informed of the purpose of the investigation and had given their consent.

Table 1 summarizes the characteristics of cirrhotic patients. For at least one week before the test, the subjects were fed a daily diet of about 3000 calories with at least $280 \mathrm{~g}$ carbohydrate. After 


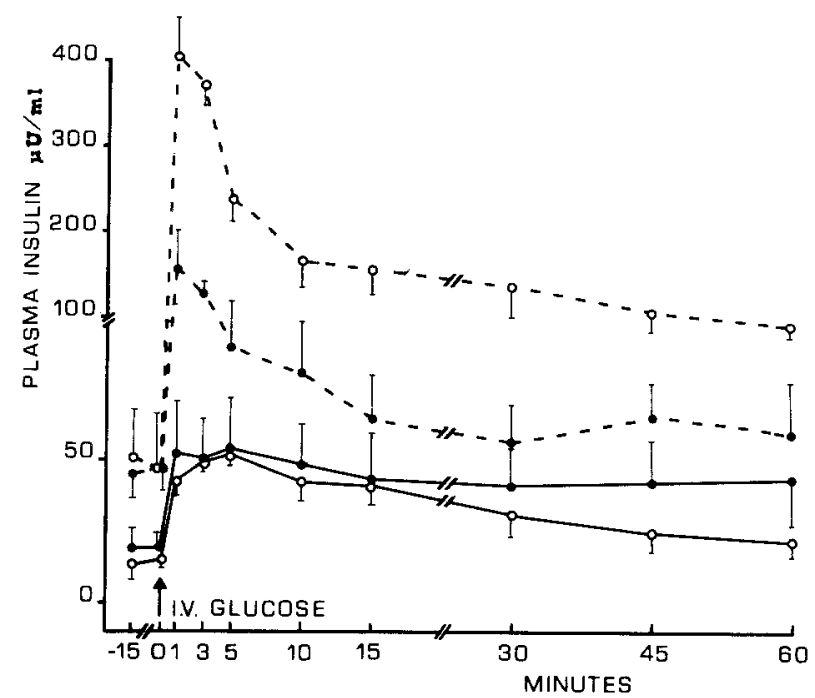

Fig. 1. Immunoreactive plasma insulin (IRI) (mean \pm SEM) in the portal vein of controls $\left(\mathrm{O}-\mathrm{-}^{-} \mathrm{O}\right)$ and of cirrhotics $(\bullet-.-\bullet)$ and in the peripheral vein of controls $\left.\left(0_{-}\right)_{0}\right)$ and of cirrhotics $(\bullet-\bullet)$, after IV glucose $(0.33 \mathrm{~g} / \mathrm{kg})$

Table 3. Portal and peripheral plasma glucose $(\mathrm{mg} / 100 \mathrm{ml}$ ) (mean \pm SEM) during and after arginine infusion $(25 \mathrm{~g})$ in control $(\mathrm{n}=$ 10) and cirrhotic subjects $(n=8)$

\begin{tabular}{|c|c|c|c|c|}
\hline \multirow[b]{2}{*}{ Time (min) } & \multicolumn{2}{|c|}{ Control Subjects } & \multicolumn{2}{|c|}{ Cirrhotic Subjects } \\
\hline & $\begin{array}{l}\text { Portal } \\
\text { vein }\end{array}$ & $\begin{array}{l}\text { Peripheral } \\
\text { vein }\end{array}$ & $\begin{array}{l}\text { Portal } \\
\text { vein }\end{array}$ & $\begin{array}{l}\text { Peripheral } \\
\text { vein }\end{array}$ \\
\hline $\begin{array}{l}\text { Baseline } \\
\text { after } \\
\text { arginine }\end{array}$ & $81 \pm 3$ & $75 \pm 4$ & $91 \pm 4$ & $83 \pm 4$ \\
\hline 1 & $87 \pm 4$ & $76 \pm 6$ & $86 \pm 5$ & $86 \pm 5$ \\
\hline 3 & $88 \pm 3$ & $77 \pm 5$ & $90 \pm 5$ & $85 \pm 4$ \\
\hline 5 & $87 \pm 3$ & $78 \pm 4$ & $92 \pm 5$ & $89 \pm 4$ \\
\hline 10 & $89 \pm 2$ & $82 \pm 3$ & $94 \pm 5$ & $92 \pm 3$ \\
\hline 15 & $83 \pm 4$ & $88 \pm 4$ & $93 \pm 4$ & $90 \pm 5$ \\
\hline 30 & $86 \pm 4$ & $87 \pm 3$ & $94 \pm 4$ & $88 \pm 3$ \\
\hline 60 & $87 \pm 5$ & $85 \pm 5$ & $88 \pm 4$ & $88 \pm 3$ \\
\hline
\end{tabular}

an overnight fast, they were taken to the operating theatre and prepared as for a laparotomy. An extraperitoneal median abdominal incision was made under $1 \%$ xylocaine local anaesthesia to expose the umbilical vein, and a central venous pressure catheter (Abbott) was introduced under fluoroscopy into the left branch of the portal vein immediately beyond its point of entry into the liver. Throughout the test, the catheter was maintained patent with $0.154 \mathrm{~mol} / 1$ saline. A second catheter for the drawing of blood specimens was inserted into the median antecubital vein and also kept patent with $0.154 \mathrm{~mol} / 1$ saline.

After basal blood specimens had been obtained from both the portal and antecubital veins, patients were given an IV infusion of glucose $(0.33 \mathrm{~g} / \mathrm{kg}$ in $2 \mathrm{~min}$ ) or of arginine $(25 \mathrm{~g}$ in $30 \mathrm{~min})$. Blood samples were drawn at $1,3,5,10,30,45$ and 60 minutes. Heparinized blood specimens for insulin assay were centrifuged at $4^{\circ} \mathrm{C}$, frozen and stored at -20 until assay. For glucagon assay, $4 \mathrm{ml}$ of blood were collected into chilled tubes containing $2000 \mathrm{U}$

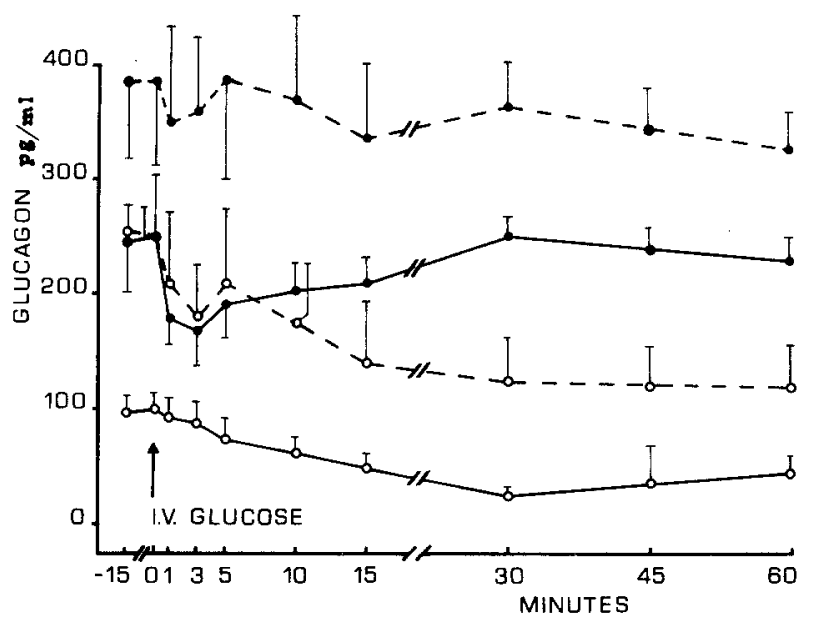

Fig. 2. Immunoreactive plasma glucagon (IRG) (mean \pm SEM) in the portal vein of controls $\left(O_{-+-}\right)$) and of cirrhotics $(\bullet---\bullet)$ and in the peripheral vein of controls $\left(\mathrm{O}_{-} \mathrm{O}\right)$ and of cirrhotics $(-\bullet)$, after IV glucose $(0.33 \mathrm{~g} / \mathrm{kg})$

of aprotinin $(10,000 \mathrm{~K} . \mathrm{I} . \mathrm{U} . / \mathrm{ml})$ and $0.2 \mathrm{ml}$ of $2.4 \mathrm{~g} / 100 \mathrm{ml}$ ethylenediaminetetracetic acid disodium (EDTA) (1.2 g/l blood); after centrifugation the plasma was separated and frozen until assay.

Plasma glucose was determined enzymatically with a Beckman analyzer. The fractional clearance rate for glucose $\left(K_{G}\right)$ was calculated according to the method of Conard et al. (7). Plasma insulin (IRI) was estimated by radioimmunoassay (23). Glucagon (IRG) was measured by radioimmunoassay with the $30 \mathrm{~K}$ antibody of Unger (43). Sensitivity of the assay was about $25 \mathrm{pg} / \mathrm{ml}$; an intrassay coefficient of variation of $11 \%$ and an interassay variation of $15 \%$ was obtained at $150 \mathrm{pg} / \mathrm{ml}$.

During the test, portal pressure was measured manometrically; values below $15 \mathrm{~cm} \mathrm{H}_{2} \mathrm{O}$ were considered normal.

Data are presented as the mean \pm SEM. Results were evaluated by Student's unpaired and paired $t$ tests.

\section{Results}

All cirrhotic patients had high portal vein pressure $\left(41 \pm 7 \mathrm{~cm} \mathrm{H}_{2} \mathrm{O}\right.$ ).

\section{Intravenous Glucose Tolerance Tests}

After IV injection of glucose $(0.33 \mathrm{~g} / \mathrm{kg})$ fractional clearance rate was lower in cirrhotic patients $(0.67 \pm$ $0.20 \% / \mathrm{min})$ than in non-cirrhotic subjects $(1.91 \pm$ $0.18 \% / \mathrm{min} ; \mathrm{P}<0.001$ ).

Glucose space was increased in cirrhotic patients (cirrhotics, $15.2 \pm 1.2$; controls, $9.9 \pm 0.2 ; \mathrm{P}<$ $0.001)$.

The insulin pattern in cirrhotics was different from that of the controls (Fig. 1). Peripheral insulin levels were significantly higher in the cirrhotic group at $45(\mathrm{P}<0.001)$ and $60(\mathrm{P}<0.001)$ minutes. Portal insulin concentrations in cirrhotic patients were 


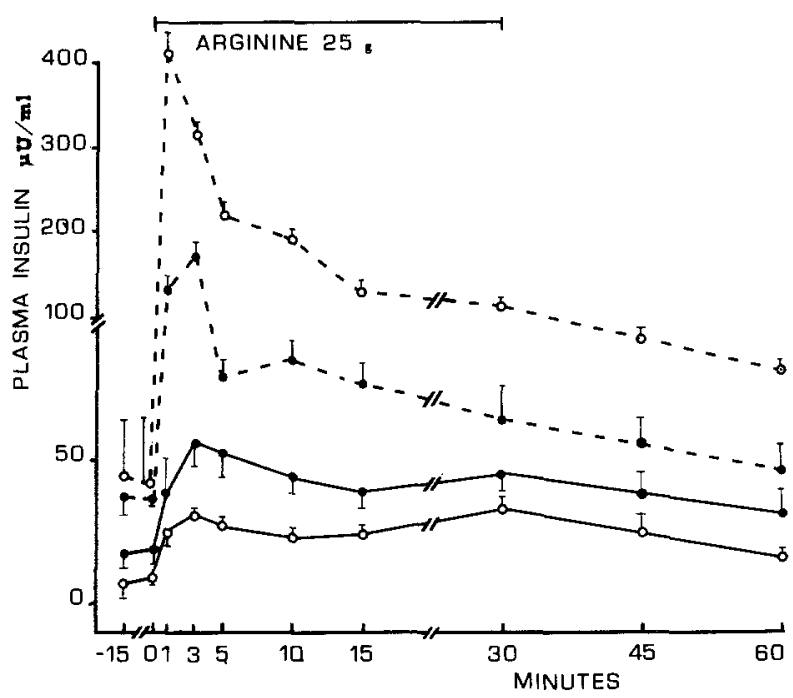

Fig. 3. Immunoreactive plasma insulin (IRI) (mean \pm SEM) in the portal vein of controls $\left(\mathrm{O}_{--\ldots}\right)$ and of cirrhotics $(\bullet-\cdots)$ and in the peripheral vein of controls $(\mathrm{O}-\mathrm{O})$ and of cirrhotics $(\bullet-\bullet)$, after arginine infusion ( $25 \mathrm{~g}$ in $30 \mathrm{~min}$ )

lower than in controls. This is expressed as area under the insulin curve in Table 2. Portal: peripheral insulin ratios were consistently lower in cirrhotic subjects than controls. There was no significant correlation between peripheral vein insulin concentration and portal pressure.

Figure 2 shows the portal and peripheral vein IRG response to a 2-minute glucose infusion. Portal IRG values were higher than those in peripheral plasma in both groups. Basal plasma glucagon concentration was higher in cirrhotic than control subjects both in portal $(385 \pm 76$ versus $250 \pm 65 \mathrm{pg} /$ $\mathrm{ml}$; N.S. $)$ and peripheral venous blood $(250 \pm 27$ versus $105 \pm 15 \mathrm{pg} / \mathrm{ml} ; \mathrm{P}<0.001)$. A rapid decrease in portal and peripheral vein IRG concentrations occurred during glucose infusion in normals but not in cirrhotic subjects.

\section{Arginine Tolerance Tests}

Portal vein glucose concentration (Table 3 ) did not change with arginine infusion in controls and cirrhotics. Peripheral plasma glucose concentration rose, however, in controls $(\mathrm{P}<0.0005$, paired $\mathrm{t}$ test $)$, but not in cirrhotic subjects.

Figure 3 shows the portal and peripheral vein insulin responses to a $25 \mathrm{~g}$ arginine infusion in 30 minutes. In control subjects basal portal vein insulin concentration was four times higher $(41 \pm 5 \mu \mathrm{U} / \mathrm{ml})$ than in the peripheral vein $(10 \pm 3 \mu \mathrm{U} / \mathrm{ml})$ while in cirrhotics basal portal concentration was only twice as high $(36 \pm 2 \mu \mathrm{U} / \mathrm{ml}$ versus $19 \pm 4 \mu \mathrm{U} / \mathrm{ml})$. Peak

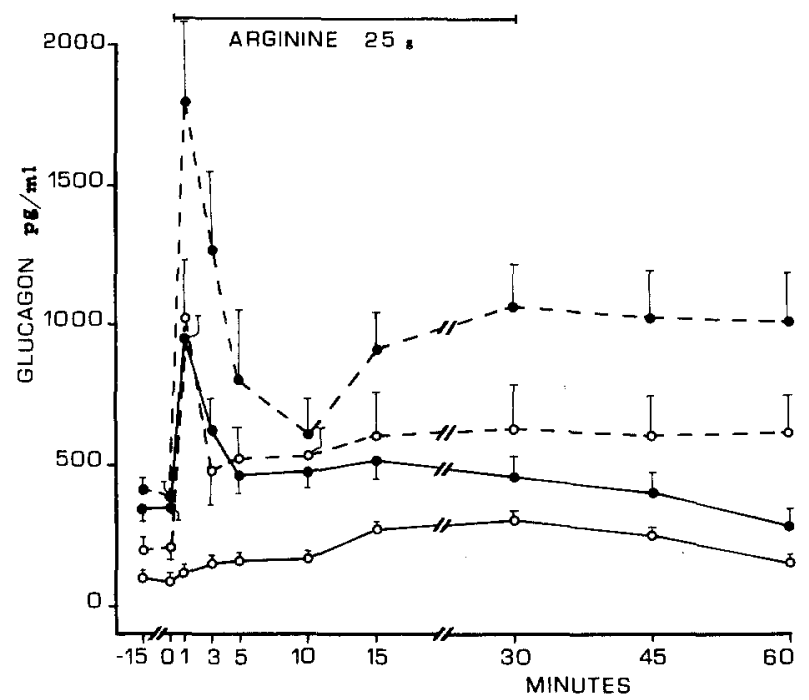

Fig. 4. Immunoreactive plasma glucagon (IRG) (mean \pm SEM) in the portal vein of controls $(0---0)$ and of cirrhotics $(\bullet---\bullet)$ and in the peripheral vein of controls $\left(\mathrm{O}_{-} \mathrm{O}\right)$ ) and of cirrhotics $(\bullet-\bullet)$, after arginine infusion $(25 \mathrm{~g}$ in $30 \mathrm{~min})$

portal vein IRI concentration was reached more rapidly $(1 \mathrm{~min})$ in controls $(413 \pm 25 \mu \mathrm{U} / \mathrm{ml})$ than in cirrhotics $(3 \mathrm{~min})(168 \pm 16 \mu \mathrm{U} / \mathrm{ml})$; peak peripheral IRI levels were attained within 3 minutes in both controls $(31 \pm 2 \mu \mathrm{U} / \mathrm{ml})$ and cirrhotics $(57 \pm 8 \mu \mathrm{U} /$ $\mathrm{ml})$. Portal insulin concentrations in cirrhotics were significantly lower than in controls $(\mathrm{P}<0.01$, paired $t$ test); whereas, peripheral insulin levels were higher in cirrhotics than in controls $(\mathrm{P}<0.0005$, paired $\mathrm{t}$ test).

Table 2 shows the portal to peripheral insulin ratios for the integrated area under the curve. Again the portal: peripheral insulin ratio was consistently lower in cirrhotics than in control subjects.

Figure 4 illustrates the portal and peripheral vein IRG response to arginine. In controls, basal portal venous IRG values were $46 \%$ higher than peripheral. The peak portal vein IRG concentration was reached rapidly i.e. within one minute $(1026 \pm 208 \mathrm{pg} / \mathrm{ml})$ and subsequent peripheral vein IRG concentrations were one half to one third of the portal values. Basal plasma glucagon was raised in cirrhotics compared with controls both in the portal $(395 \pm 40$ versus 210 $\pm 36 \mathrm{pg} / \mathrm{ml} ; \mathrm{P}<0.005)$ and peripheral veins $(350 \pm$ 37 versus $98 \pm 13 \mathrm{pg} / \mathrm{ml} ; \mathrm{P}<0.001)$. After arginine, the portal vein glucagon peak also occurred within one minute in cirrhotics $(1800 \pm 360 \mathrm{pg} / \mathrm{ml})$ and portal IRG levels remained high throughout the 60 minutes of the test. Peripheral venous plasma glucagon concentrations in cirrhotic patients, as in controls, were $50 \%$ of those found in the portal vein. 


\section{Discussion}

Insulin concentrations are higher in the portal than in the peripheral circulation in normal man and animals $[3-5,11,25,28,34]$. The liver is a major site of insulin breakdown and it has been suggested that up to $50 \%$ of secreted insulin is degraded in a single transhepatic passage $[13,20,22,23,29,32,33,35$, $36,38]$. Peripheral insulin concentrations therefore reflect a balance between insulin secretion and degradation and peripheral hyperinsulinaemia may result not only from increased insulin secretion, but also from diminished degradation.

Other workers have shown elevated peripheral insulin levels in chronic liver disease $[2,6,8,12,14$, $24,31,37,42]$ and this is confirmed in our study. Direct measurement of portal and peripheral venous insulin concentrations in our control and cirrhotic patients gives more direct information about insulin secretion than peripheral insulin measurement alone. Our finding of decreased portal concentrations despite peripheral hyperinsulinaemia after glucose and arginine in the cirrhotic subjects, suggests that high peripheral insulin concentrations are the result of diminished insulin metabolism by the diseased liver. This may result from parenchymal damage itself or portal systemic shunting of blood.

Support in favour of this hypothesis comes from the work of Johnston et al., with simultaneous insulin and C-peptide measurements in cirrhotic subjects [18] and patients with longstanding portal venous block [19]. Their data suggests that parenchymal damage may be more important than portal systemic anastomosis and this is also suggested by the lack of correlation in our cirrhotics between peripheral insulin levels and portal pressure.

The low portal insulin concentrations suggest that the pancreas in cirrhotic patients is under-secreting insulin despite peripheral hyperinsulinaemia. Insulin secretion in response to arginine was delayed as well as decreased. This is also seen in early diabetes mellitus [10] and further suggests a pancreatic defect. The nature of this pancreatic abnormality is uncertain.

Glucagon in normal man and animals is also degraded by the liver $[1,17,21,26,36]$, but substantial glucagon metabolism occurs in other tissues, particularly the kidney $[27,39]$. High glucagon concentrations in peripheral blood of patients with chronic liver disease have been demonstrated by other workers $[14,30,40-42]$ with values highest in those with known portal systemic anastomoses [30, 42]. This is again confirmed in our study, but, unlike insulin, portal glucagon concentrations were also raised, suggesting hypersecretion of the hormone. Without meas- urement of portal blood flow, it is not possible to comment on the efficiency of hepatic glucagon degradation. A recent study of Sherwin et al. [40] however, has demonstrated a normal metabolic clearance rate of glucagon in chronic liver disease, despite peripheral hyperglucagonaemia. This supports our conclusion that a true hypersecretory state exists for glucagon.

Acknowledgements. We thank the editors for their helpful advice during the editing of the manuscript.

\section{References}

1. Assan, R.: In vivo metabolism of glucagon. In: Glucagon. Molecular, physiology, clinical and therapeutic implications. Lefebvre, P. J., Unger, R. H. (Eds.), pp. 47-59. Oxford: Pergamon 1972

2. Berkowitz, D.: Glucose tolerance, free fatty acid, and serum insulin responses in patients with cirrhosis. Am. J. Dig. Dis. 14, 691-699 (1969)

3. Bittner, R., Beger, H. G., Kraas, E.: Oscillation in insulin response to glucose stimulation. Measurements in the portal vein in the postoperative period. Horm. Metab. Res. 6, 423-424 (1974)

4. Blackard, W. G., Rubenstein, A. H.: Proinsulin, insulin and Cpeptide concentrations in human portal and peripheral blood. J. Clin. Invest. 55, 1278-1283 (1975)

5. Cerasi, E., Hallberg, D., Luft, R.: Simultaneous determination of insulin in brachial and portal veins during glucose infusion in normal and prediabetic subjects. Horm. Metab. Res. 2, 303-304 (1970)

6. Collins, J. R., Crofford, O. B.: Glucose intolerance and insulin resistance in patients with liver disease. Arch. Intern. Med. 124, 142-148 (1969)

7. Conard, V.: Mesure de l'assimilation du glucose; bases théoriques et applications cliniques. Acta Gastroenterol. Belg. 18, 655-705 (1955)

8. Creutzfeldt, W., Frerichs, H., Kraft, W.: The intravenous tolbutamide test in liver disease. Acta Diabetol. Lat. 4 [Suppl. 1], 209-230 (1967)

9. Duprey, J., Lubetzki, J., Warnet, A.: Étude de la tolérance au glucose, de l'insuline-sécrétion et de la sensibilité a l'insuline endogène au cours des affections alcooliques du foie. Diabète 22, 143-149 (1974)

10. Efendic, S., Cerasi, E., Luft, R.: Quantitative study on the potentiating effect of arginine on glucose-induced insulin response in healthy, prediabetic, and diabetic subjects. Diabetes 23, 161-171 (1974)

11. Erwald, R., Hed. R., Nygren, A., Rojdmark, S., Sundblad, L., Wiechel, K. L.: Immunoreactive insulin in the portal and the peripheral venous blood after intravenous tolbutamide administration. Diabetes 20, 686-690 (1971)

12. Felber, J. P., Magnenat, P., Vannotti, A.: Tolèrance au glucose diminuée et réponse insulinique élevée dans la cirrhose. Schweiz. Med. Wochenschr. 97, 1537-1539 (1967)

13. Franckson, J. R. M., Ooms, H. A.: The catabolism of insulin in the dog: evidence for two catabolic pathways. Postgrad. Med. J. 49, 931-939 (1974)

14. Greco, A. V., Ghirlanda, G., Patrono, C., Fedeli, G., Manna, R.: Behavior of pancreatic glucagon, insulin and $\mathrm{HGH}$ in liver cirrhosis after arginine and i.v. glucose. Acta Diabetol. Lat. 11, 330-339 (1974) 
15. Herbert, V., Lau, K. S., Gottlieb, C. W., Bleicher, S. J.: Coated charcoal immunoassay of insulin. J. Clin. Endocrinol. Metab. 25, 1375-1384 (1965)

16. Hernandez, A., Zorrilla, E., Gershberg, H.: Decreased insulin production, elevated growth hormone levels and glucose intolerance in liver disease. J. Lab. Clin. Med. 73, 25-33 (1969)

17. Jaspan, J. B., Huen, A. H. J., Morley, C. G., Moosa, A. R., Rubenstein, A. H.: The role of the liver in glucagon metabolism. J. Cin. Invest. 60, 421-428 (1977)

18. Johnston, D. G., Alberti, K. G. M. M., Faber, O. K., Binder, C., Wright, R.: Hyperinsulinism of hepatic cirrhosis: diminished degradation or hypersecretion? Lancet 1977 I, $10-12$

19. Johnston, D. G., Alberti, K. G. M. M., Wright, R., SmithLaing, G., Stewart, A. M., Sherlock, S., Faber, O., Binder, C.: C-peptide and insulin in liver disease. Diabetes 27 [Suppl. 1], 201-206 (1978)

20. Kaden, M., Harding, P., Field, J. B.: Effect of intraduodenal glucose administration on hepatic extraction of insulin in the anesthetized dog. J. Clin. Invest. 52, 2016-2028 (1973)

21. Kakiuchi, S., Tomizawa, H. H.: Properties of a glucagondegrading enzyme of beef liver. J. Biol. Chem. 239, 2160-2164 (1964)

22. Kanazawa, Y., Kukuya, T., Ide, T., Kosaka, K.: Plasma insulin responses to glucose in femoral, hepatic, and pancreatic veins in dogs. Am. J. Physiol. 211, 442-448 (1966)

23. Kaplan, N., Madison, L. L.: Effect of endogenous insulin secretion on the magnitude of hepatic binding of labelled-insulin during a single transhepatic circulation in human subjects. Clin. Res. 7, 248 (1959)

24. Kasperska, T., Lawecki, J., Rogala, H., Czyzyk, A.: The behaviour of insulinaemia in patients with liver cirrhosis after intravenous administration of glucose, tolbutamide and glucagon. Diabetologia 7, 391-394 (1971)

25. Kraas, E., Bittner, R., Meves, M., Beger, H. G.: Insulinkonzentrationen in Pfortaderblut des Menschen nach GlucoseInfusion. Klin. Wochenschr. 52, 404-406 (1976)

26. Lefebvre, P., Fischer, U., Jutzi, E., Hommel, H., Luyckx, A. S.: Rôle du foie dans la captation du glucagon endogène chez le chien anesthésié. Ann. Endocrinol. (Paris) 39, 347-348 (1978)

27. Lefebvre, P. J., Luyckx, A. S.: Effect of acute kidney exclusion of renal arteries on peripheral plasma glucagon levels and pancreatic glucagon production in the anesthetized dog. Metabolism 24, 1169-1183 (1975)

28. Lund, B., Schmidt, A., Deckert, T.: Portal and cubital serum insulin during oral, portal and cubital glucose tolerance tests. Acta Med. Scand. 197, 275-281 (1975)

29. Madison, L. L., Combes, B., Unger, R. H., Kaplan, N.: The relationship between the mechanism of action of the sulphonylureas and the secretion of insulin into the portal circulation. Ann. N.Y. Acad. Sci. 74, 548-556 (1959)

30. Marco, J., Diego, J., Villanueva, M. L., Diaz-Fierros, M., Valverde, I., Segovia, J. M.: Elevated plasma glucagon levels in cirrhosis of the liver. N. Engl. J. Med. 289, 1107-1111 (1973)
31. Megyesi, C., Samols, E., Marks, V.: Glucose tolerance and diabetes in chronic liver disease. Lancet 1967 II, 1051-1055

32. Mondon, C. E., Olefsky, J. M., Dolkas, C. B., Reaven, G. M.: Removal of insulin by perfused rat liver: effect of concentration. Metabolism 24, 153-160 (1975)

33. Mortimer, G. E., Tietze, F., Stetten, D.: Metabolism of insulin- $\mathbf{I}^{131}$, studies in isolated, perfused rat liver and hind limb preparations. Diabetes 8, 307-314 (1959)

34. Rayfield, E. J., Faulkner, R.T., Czajkowski, W.: Portal and peripheral vein insulin responses to intravenous glucose in the rhesus monkey. J. Lab. Clin. Med. 87, 919-924 (1976)

35. Record, C. O., Alberti, K.G.M.M., Williamson, D. H., Wright, R.: Glucose tolerance and metabolic changes in human viral hepatitis. Clin. Sci. Mol. Med. 45, 677-690 (1973)

36. Röjdmark, S., Bloom, G., Chou, M. C. Y., Field, J. B.: Hepatic extraction of exogenous insulin and glucagon in the dog. Endocrinology 102, 806-813 (1978)

37. Samaan, N. A., Stone, D. B., Eckhardt, R. D.: Serum glucose, insulin and growth hormone in chronic hepatic cirrhosis. Arch. Intern. Med. 124, 149-152 (1969)

38. Samols, E., Ryder, J. A.: Studied on tissue uptake of insulin in man using differential immunoassay for endogenous and exogenous insulin. J. Clin. Invest. 40, 2092-2102 (1961)

39. Sherwin, R. S., Bastl, C., Finkelstein, F. O., Fisher, M., Black, H., Hendler, R., Felig, P.: Influence of uremia and hemodialysis on the turnover and metabolic effects of glucagon. J. Clin. Invest. 57, 722-731 (1976)

40. Sherwin, R. S., Fisher, M., Bessoff, J., Snyder, N., Hendler, R., Conn, H. O., Felig, P.: Hyperglucagonemia in cirrhosis: altered secretion and sensitivity to glucagon. Gastroenterology 74, 1224-1228 (1978)

41. Sherwin, R., Joshi, P., Hendler, R., Felig, P., Conn, H. O.: Hyperglucagonemia in Laennec's cirrhosis. N. Engl. J. Med. 290, 239-242 (1974)

42. Shurberg, J. L., Resnick, R. H., Koff, R. S., Ross, E., Baum, R. A., Pallotta, J. A.: Serum lipids, insulin and glucagon after portacaval shunt in cirrhosis. Gastroenterology 72, 301-304 (1977)

43. Unger, R. H., Eisentraut, A. M., McCall, M.S., Madison, L. L.: Measurements of endogenous glucagon in plasma and the influence of blood glucose concentration upon its secretion. J. Clin. Invest. 41, 682-689 (1962)

Received: May 22, 1978

and in revised form: April 3, 1979

Dr. A. V. Greco

Istituto di Patologia Medica

Catholic University

Largo Gemelli 8

I-00168 Rome

Italy 